book focuses on World War II and its more immediate aftermath, not the Power movement era and its demise.

Black Power, Yellow Power, and the Making of Revolutionary Identities is a significant contribution to the scholarship on comparative racialization and political mobilization. It is primarily a suggestive work, though, that focuses on the transmission and interpretation of select "texts" and "ideas." A greater attention to social and historical contextualization as well as gender analysis could have strengthened the insights of this book.

Judy Tzu-Chun Wu

Ohio State University

\title{
Nelson Lichtenstein and Elizabeth Tandy Shermer, eds. The Right and Labor in America: Politics, Ideology, and Imagination (Philadelphia: University of Pennsylvania Press, 2012).
}

While historians have spilled much ink recounting in detail the violence and political attacks that anti-union forces have visited upon labor and its supporters, it is only in recent years that they have turned their attention to studying those anti-union forces themselves. Understanding how and why these movements developed is essential for understanding labor's decline and the rightward political shift in recent decades.

Lichtenstein and Shermer's edited volume, The Right and Labor in America, is a welcome addition to this body of work. Over fourteen wide-ranging chapters, the contributors show how anti-unionism is not merely an issue that many U.S. conservatives have championed in the twentieth century. Rather, "hostility to trade unionism per se was a crystallizing impulse for the modern American conservative movement" (8).

Many of the chapters focus on the development of modern conservatism's "rhetoric of reaction," to use Hirschman's apt expression. From the evolution of "free trade," to the cry for "states' rights," to the development of "humanist" management, to the emergence of the "right to work" movement, conservative activists and intellectuals mobilized around powerful national tropes of rights and freedom.

But the articulation of such tropes, and their mobilization in the service of right-wing causes, was far from a smooth and inevitable process. As many of the authors show, it was often contingent and riven with conflict. Take for example Michael Pierce's fascinating study of the political evolution of Arkansas Governor Orval Faubus. While he is primarily known today for his stand against racial integration at Little Rock Central High School, Faubus began his political life steeped in a rural Ozark socialist tradition, and was initially elected with the support of a bi-racial, labor-backed coalition. However, with the rise of "massive 
resistance" to integration, Faubus recognized the grassroots nature of the segregationist movement. He seized the opportunity to advance a new kind of rightwing populism based on a racist appeal to white working class voters. This move split the white working class from its past pro-labor position, paving the way for the patriarchal corporate cultures of Walmart and Tyson that came to dominate the state - and much of the country - in the latter part of the $20^{\text {th }}$ century.

The Faubus episode highlights the complex inter-relation of race, class, and region in the creation of the modern conservative movement. The South is certainly critical here, and several authors focus on that region's key role in development of anti-union ideologies and strategies, such as right-to-work laws, capital flight, and union avoidance campaigns. But the South is not alone. Reuel Schiller's chapter on the failed campaign for right-to-work in California, and Alexander Gourse's chapter on fair employment policy in Illinois both show how this dynamic shaped conservative movements in other parts of the country, often in unexpected ways.

Also critical to understanding the right of anti-union conservatism was its successful re-framing of unions' role in society and politics. After seeing unions establish themselves as a legitimate and formidable force for social equality and progressive policy during the New Deal, employers and their ideological allies mounted a concerted campaign to delegitimize and undermine labor.

Key to this project were efforts to paint unions as greedy, corrupt, "special interests," profiting off the hard work of their individual members, whose hard-earned dues money was being put to use for purposes over which they had little control. Several of the book's chapters show how political campaigns for right-to-work laws, legal defense against so-called "compulsory unionism," and selective investigation of union corruption, allowed conservatives to position themselves as the defenders of individual freedom against the tyranny of "union bosses" and their bureaucracies. While this was a decidedly minority position in the postwar decades, by century's end it was ascendant.

Conservatives expanded their influence by appropriating the techniques and rhetoric of progressive movements, particularly civil rights. Sophia Lee's chapter on legal battles surrounding right-to-work legislation examines this process in detail. She shows how the National Right To Work Legal Defense Foundation (NRWLDF) explicitly modeled itself after the NAACP's LDF, wrapping its arguments in the rhetoric of civil rights and constitutionalism. According to them, "the struggle for the right-to-work was not merely like the black freedom struggle, it was part of it" (173).

The final chapters on the continued failure of labor law reform in the 1990s and 2000s show how the Right has been able to reap the fruits of their postwar labor. With unions reduced to narrow "special interests," policy to protect workers' rights appeared not as legitimate regulatory legislation, but rather as an unfair, undemocratic payoff for a partisan constituency. 
While The Right and Labor in America offers a series of interesting vignettes, its structure does not always hang together cohesively. Many readers will likely find themselves picking and choosing the chapters most relevant to their interests. But overall, Lichtenstein, Shermer, and their contributors should be commended for contributing to a deeper understanding of the essential role of labor in the shaping of contemporary American culture and politics.

\section{Barry Eidlin \\ University of Wisconsin-Madison}

\section{Gillian McCann, Vanguard of the New Age: The Toronto Theosophical Society, 1891-1945 (Montreal, Kingston: McGill-Queen's University Press, 2012).}

So many interesting social and religious movements occur along the edges of a culture. Helena Petrovna Blavatsky, Henry Steel Olcott, and William Quan Judge founded the International Theosophical Society in New York in 1875. They championed mysticism and spiritualism in what they saw as an apocalyptic battle with science and materialism. The answers to the problems of the modern world, they maintained, were to be found in a body of esoteric knowledge - the "secret doctrine" - that had been entrusted to a group of Masters who had achieved immortality and were now living in India and Tibet. Theosophy claimed to be at once syncretic (drawing together the best elements of all religious faiths) and prophetic (proclaiming the imminent advent of the new age). It was doctrinally amorphous and division and crisis marked the history of the international movement. New prophets were proclaimed, utopian colonies founded, groups expelled, and the tensions between the American section of the movement and the international headquarters in Adyar, India were never effectively resolved. Nonetheless, the movement helped to introduce eastern culture to the west ("sympathetic orientalism"), and individual theosophists played a significant role in the independence movement in India and the Irish Literary Renaissance. There is a statute of Olcott outside the railway station in Colombo, Sri Lanka.

The Toronto Theosophical Society (TTS) was by far the most important grouping of Theosophists in Canada, and Gillian McCann's fine study traces both the internal workings of the Toronto society as well as its considerable impact on Canadian culture. In the first instance the TTS was shielded from some of the major scandals that rocked the international movement by the steadying influence of the central character in McCann's narrative, Albert E. S. Smythe. Born in the north of Ireland Smythe was introduced to theosophy on his way out to Canada by William Quan Judge, the president of the American Theosophical Society. Young Albert's conversion was immediate and complete. A journalist by profession he founded the TTS in 1891 and effectively led the 